\title{
Kepatuhan Tenaga Kesehatan Terhadap Implementasi Hand Hygiene di Rumah Sakit Umum Daerah Haji Kota Makassar
}

\section{The Compliance of Health Workers toward the Implementation of Hand Hygiene at the Hajj Regional Public Hospital in Makassar City}

\author{
Nur Hidayah ${ }^{1}$, Nur Fadhliyah Ramadhani ${ }^{2}$ \\ ${ }^{12}$ Keperawatan Fakultas Kedokteran dan Ilmu Kesehatan UIN Alauddin Makassar \\ Corresponding author: (nur.hidayah@uin-alauddin.ac.id, \\ nurfadhliyahramadhani@gmail.com)
}

\begin{abstract}
ABSTRAK
Kegagalan untuk melakukan hand hygiene dengan benar merupakan penyebab utama Infeksi nosokomial dan penyebaran mikroorganisme multiresisten di fasilitas pelayanan kesehatan. Berdasarkan hasil data awal yang diperoleh dari sumber data RSUD Haji Kota Makassar di dapatkan hasil bahwa tingkat kepatuhan tenaga kesehatan dalam melaksanakan hand hygiene pada bulan April sampai Juni 2017 hanya sebesar 63,75\% dari nilai standar yang ditetapkan yaitu $80 \%$. Penelitian ini bertujuan untuk mengetahui gambaran kepatuhan hand hygiene tenaga kesehatan. Desain penelitian menggunakan deskriptif observasional dengan desain cross sectional. Sampel penelitian adalah 70 tenaga kesehatan dan seluruh tindakan cuci tangan yang dilakukan tenaga kesehatan (perawat, bidan, dan dokter). Hasil penelitian menunjukkan kepatuhan perawat (56.05\%), bidan (53.37\%), dan dokter (49.33\%). Berdasarkan kepatuhan per indikasi sebelum kontak dengan pasien (55.81\%), sebelum tindakan aseptik (56.41\%), setelah terpapar cairan tubuh pasien yang berisiko (70.11\%), setelah kontak dengan pasien (53.16\%) dan setelah menyentuh lingkungan sekitar pasien (27.27)\%. Kesimpulan menunjukkan bahwa kepatuhan hand hygiene tenaga kesehatan paling tinggi dilakukan oleh perawat. Kepatuhan tertinggi berdasarkan indikasi hand hygiene dilakukan pada momen setelah terpapar cairan tubuh pasien.
\end{abstract}

Kata Kunci: Kepatuhan, Hand Hygiene, Tenaga Kesehatan

\section{ABSTRACT}

Failure in performing hand hygiene properly is the major cause of nosocomial infection and the spread of multi-resistant microorganisms in health care facilities. Based on the preliminary data obtained from the data source at the Hajj Regional Public Hospital in Makassar City, the results show that the level of compliance of health workers in implementing hand hygiene in April to June 2017 was only 63.75\% from the standard value set of $80 \%$. This research aims to identify the compliance of health workers in implementing hand hygiene. The research applies descriptive observational approach with cross sectional design. Samples of this research are 70 health workers with all actions of washing hands by the health workers (nurses, midwives, and doctors). The results indicate the compliance of nurses for about $56.05 \%$, midwives $53.37 \%$, and doctors $49.33 \%$. For compliance based on indications, the performance of hand hygiene before in contact with the patient takes about $55.81 \%$, before the aseptic action about $56.41 \%$, after exposure to the patient's harmful body fluids $70.11 \%$, after in contact with the patient $53.16 \%$, and after related to the patient's environment $27.27 \%$. The conclusion shows that the compliance of health workers toward the implementation of 
hand hygiene, the highest is conducted by nurses. While based on the indication, hand hygiene is highly performed after being exposed to the patient's body fluids.

Keywords: Compliance, Hand Hygiene, Health Workers

\section{PENDAHULUAN}

Penyakit infeksi atau menular masih merupakan masalah kesehatan global dan nasional. Ini terjadi karena adanya interaksi antara mikrooganisme dengan tubuh yang rentan. Pada umumnya pasien yang datang ke rumah sakit sudah dalam keadaan lemah atau parah. Oleh karena itu sering diperlukan tindakan "invasive” dan tindakan medis yang dapat menyebabkan mudahnya patogen penyebab infeksi masuk ke dalam tubuh pasien. Keadaan ini akan semakin memperparah penyakit yang diderita dan bahkan dapat menyebabkan kematian (Depkes, 2010). Infeksi terkait perawatan kesehatan atau Healthcare Associated Infections (HAIs), yang juga disebut sebagai infeksi "Nosokomial" atau infeksi rumah sakit (Hospital Acquired Infections/HAI) adalah infeksi yang terjadi pada pasien selama perawatan di rumah sakit atau fasilitas perawatan kesehatan lainnya dalam kurun waktu 48-72 jam (WHO, 2016).

Hasil survey yang dilakukan WHO pada tahun 2016, menyatakan bahwa angka kejadian Infeksi nosokomial di Eropa lebih dari 4 juta-4,5 juta pasien setiap tahun. Di Amerika Serikat, diperkirakan sekitar 1,7 juta pasien terkena infeksi nosokomial setiap tahun, ini mewakili prevalensi 4,5\% untuk 99.000 kematian (WHO, 2016). Depkes RI melakukan survey pada tahun 2013 di 10 RSU Pendidikan, diperoleh angka infeksi nosokomial cukup tinggi yaitu sebesar 6-16\% dengan rata-rata 9,8\%. Survey yang dilakukan di 11 rumah sakit di DKI Jakarta menunjukkan bahwa 9,8\% pasien rawat inap mendapat infeksi yang baru selama dirawat. Selain itu, data survey menunjukkan kejadian infeksi nosokomial di rumah sakit pemerintah dengan jumlah pasien 1.527 orang dari jumlah pasien beresiko 160.417 (55,1\%), sedangkan untuk rumah sakit swasta dengan jumlah pasien 991 pasien dari jumlah pasien beresiko 130.047 (35,7\%). Untuk rumah sakit ABRI dengan jumlah pasien 254 pasien dari jumlah pasien beresiko 1.672 (9,1\%), (Hamzah, 2017).

Pemerintah Indonesia telah mengeluarkan kebijakan pencegahan infeksi di rumah sakit dan fasilitas kesehatan lainnya. Kebijakan itu tertuang dalam keputusan Menteri Kesehatan Nomor 270/Menkes/III//2007 tentang Pedoman Manajerial Pengendalian infeksi di Rumah Sakit dan Fasilitas Kesehatan. Keputusan Menkes Nomor 381/Menkes/III/2007 mengenai Pedoman Pengendalian infeksi di Rumah Sakit dan 
Nur Hidayah, Nur Fadhliyah Ramadhani : Jurnal The Compliance of Health ....

Fasilitas Kesehatan. Keputusan Menkes Nomor 129 tahun 2008 mengenai Standar Pelayanan Minimal Rumah Sakit menetapkan standar kejadian Infeksi nosokomial di rumah sakit $\leq 1,5 \%$. Kebijakan tersebut sebagai upaya untuk memutuskan siklus penularan penyakit dan melindungi pasien, petugas kesehatan, pengunjung, dan masyarakat yang menerima pelayanan baik di rumah sakit maupun pelayanan kesehatan lainnya (Depkes RI, 2008).

Upaya pencegahan infeksi nosokomial yang dapat dilakukan oleh tenaga kesehatan adalah meningkatkan kemampuan dalam penerapan kewaspadaan standar dengan komponen utama yang merupakan salah satu metode paling efektif untuk mencegah penularan patogen berkaitan dengan pelayanan kesehatan adalah dengan melakukan praktek kebersihan tangan (hand hygiene) (WHO, 2009).

Hand hygiene merupakan suatu upaya pencegahan infeksi yang ditularkan melalui tangan dengan cara menghilangkan kotoran dan debris serta menghambat atau membunuh mikroorganisme pada kulit yang diperoleh dari kontak antara pasien dengan lingkungan. Kegagalan untuk melakukan hand hygiene dengan baik dan benar merupakan penyebab utama Infeksi nosokomial dan penyebaran mikroorganisme multiresisten di fasilitas pelayanan kesehatan (Perry \& Potter, 2002 dalam Depkes RI, 2008).

Program untuk meningkatkan hand hygiene petugas kesehatan telah dideklarasikan oleh WHO melalui program keselamatan pasien yang mencetuskan Global Patient Safety Challenge "clean care is safe care". WHO juga meluncurkan Save Lives: Clean Your Hands dengan strategi 5 momen hand hygiene (My Five Moments for Hand hygiene) yaitu sebelum kontak dengan pasien, sebelum melakukan prosedur aseptik, setelah terpapar dengan cairan tubuh pasien, setelah kontak dengan pasien, setelah kontak dengan lingkungan sekitar pasien” (WHO, 2009).

Kepatuhan tenaga kesehatan dalam melakukan hand hygiene sangat penting dilakukan karena ketidakpatuhan dapat menimbulkan dampak antara lain: (1) Bagi pasien, terjadi penambahan diagnosa penyakit dan memperpanjang jumlah hari rawat selama di rumah sakit bahkan dapat menyebabkan kematian; (2) Bagi pengunjung, dapat menularkan kepada orang lain setelah meninggalkan rumah sakit; (3) Bagi perawat dan tenaga kesehatan lainnya, akan menjadi barier (pembawa kuman) yang menularkan kepada pasien lain dan diri sendiri; (4) Bagi rumah sakit, menurunkan mutu pelayanan rumah sakit hingga pencabutan ijin operasional rumah sakit, (Syamsulastri, 2017).

Studi di Amerika Serikat menunjukkan tingkat kepatuhan perawat melakukan hand hygiene masih sekitar 50\% dan di Australia masih sekitar 65\%. Sebuah study 
menunjukkan bahwa program hand hygiene di Rumah Sakit Cipto Mangunkusumo (RSCM) yang dilaksanakan sejak tahun 2008 menunjukkan bahwa kepatuhan perawat dan tenaga kesehatan lainnya melakukan cuci tangan hanya sekitar 60\%. Hal ini merupakan tantangan yang cukup besar bagi tim pengendali infeksi rumah sakit untuk mempromosikan program cuci tangan ini (Utami, 2016).

Penelitian yang dilakukan oleh Napitupulu 2014 tentang kepatuhan tenaga kesehatan dalam pelaksaan cuci tangan di Ruang Rawat Inap RSUP Haji Adam Malik Medan menunjukkan hasil yang kurang baik, hasilnya perawat (44,31\%), bidan (46,60\%), dan dokter (25,24\%) Berdasarkan kepatuhan per indikasi sebelum kontak dengan pasien (37,21\%), sebelum tindakan aseptik (30,47\%), setelah terpapar cairan tubuh pasien (46,53\%), setelah kontak dengan pasien (45,60\%), dan setelah kontak dengan lingkungan pasien (21,27\%). Hal ini sejalan dengan penelitian Sinaga tentang kepatuhan kepatuhan hand hygiene pada tahun 2015 di RS MISI di Rangkasbitung menunjukkan bahwa 44.7\% perawat tidak patuh melakukan cuci tangan (Sinaga, 2015). Hasil penelitian Marjadi (2010), menyatakan tenaga kesehatan dua kali lebih banyak melakukan hand hygiene setelah keluar ruangan dibandingkan sebelum masuk ruangan. Hal ini memberikan kesan bahwa perawat lebih mementingkan kebersihan sendiri dibandingkan risiko yang bisa diperoleh pasien, (Suhartini, 2017).

Berdasarkan hasil data awal yang diperoleh dari sumber data RSUD Haji Kota Makassar di dapatkan hasil bahwa tingkat kepatuhan tenaga kesehatan dalam melaksanakan hand hygiene pada bulan April sampai Juni 2017 hanya sebesar 63,75\% dari nilai standar yang ditetapkan yaitu $80 \%$. Selain itu observasi awal yang dilakukan oleh peniliti memberikan gambaran bahwa fasilitas yang menunjang pelaksaan hand hygiene di RSUD Haji Kota Makassar belum tertata baik di lihat dari tidak tersedianya handrub di setiap kamar pasien dan beberapa wastafel yang kurang berfungsi dengan baik.

Berdasarkan data yang menunjukkan tingginya angka kejadian infeksi nosokomial dan rendahnya tingkat kepatuhan perawat dan tenaga kesehatan lain dalam melakukan hand hygiene maka peneliti tertarik untuk mengetahui tentang kepatuhan hand hygiene petugas kesehatan di RSUD Haji Makassar khususnya pada tiga profesi tenaga kesehatan yaitu perawat, dokter, dan bidan. 
Nur Hidayah, Nur Fadhliyah Ramadhani : Jurnal The Compliance of Health ....

\section{METODE}

Metode penelitian yang digunakan adalah jenis penelitian kuantitatif dengan pendekatan deskriptif observasional dengan desain Cross Sectional Study. Penelitian ini dilakukan di RSUD Haji kota Makassar. Sampel yang digunakan sebanyak 70 responden. Teknik pengambilan sampel menggunakan teknik Stratified Random Sampling. Instrumen penelitian ini adalah kuesioner dan observasi. Pengolahan data menggunakan manual persentase.

\section{HASIL}

Berdasarkan tabel 1 didapatkan hasil bahwa tingkat kepatuhan perawat dan bidan telah melewati standar kepatuhan menurut WHO yaitu $>50 \%$, dengan kepatuhan 56.05\% dan bidan sebesar 53.37\% Sedangkan kepatuhan dokter masih berada dibawah standar WHO yaitu 49.33\% .

Tabel 1. Kepatuhan Pelaksanaan Hand Hygiene Tenaga Kesehatan Berdasarkan Kategori Profesi $(n=70)$

\begin{tabular}{lcc}
\hline \multirow{2}{*}{ Tenaga kesehatan } & Patuh & Tidak Patuh \\
\cline { 2 - 3 } & $\%$ & $\%$ \\
\hline Perawat & 56.05 & 43.95 \\
Bidan & 53.37 & 46.63 \\
Dokter & 49.33 & 50.67 \\
\hline
\end{tabular}

Berdasarkan tabel 2 didapatkan hasil bahwa kepatuhan pelaksanaan hand hygiene tenaga kesehatan kepatuhan tertinggi berada pada momen setelah terpapar cairan tubuh pasien yaitu sebesar $87.5 \%$ dan momen setelah kontak dengan lingkungan pasien merupakan momen dengan tingkat kepatuhan terendah yaitu sebesar $85.7 \%$.

Tabel 2. Pelaksanaan 5 Momen Hand Hygiene Tenaga Kesehatan $(\mathrm{n}=70)$

\begin{tabular}{lcccc}
\hline \multicolumn{1}{c}{ Momen } & \multicolumn{2}{c}{ Patuh } & \multicolumn{2}{c}{ Tidak Patuh } \\
\cline { 2 - 5 } & F & $\%$ & F & $\%$ \\
\hline Sebelum kontak dengan pasien & 7 & 43.7 & 9 & 56.3 \\
$\begin{array}{l}\text { Sebelum tindakan aseptik } \\
\begin{array}{l}\text { Setelah terpapar cairan tubuh } \\
\text { pasien }\end{array}\end{array}$ & 9 & 75.0 & 3 & 25.0 \\
$\begin{array}{l}\text { Setelah kontak dengan pasien } \\
\begin{array}{l}\text { Setelah kontak dengan lingkungan } \\
\text { pasien }\end{array}\end{array}$ & 5 & 87.5 & 2 & 12.5 \\
\hline
\end{tabular}


Berdasarkan tabel 3 hasil observasi menunjukkan pelaksanaan prosedur hand hygiene perawat dan bidan dominan menggunakan air dan sabun atau handwash yaitu sebesar 52\% oleh perawat dan $60 \%$ oleh bidan sedangkan dokter lebih sering menggunakan handrub yaitu sebesar $71.4 \%$.

Tabel 3. Penggunaan Handwash dan Handrub dalam Pelaksanaan Hand Hygiene Tenaga Kesehatan Berdasarkan Kategori Profesi (n=37)

\begin{tabular}{lcccc}
\hline \multirow{2}{*}{ Tenaga kesehatan } & \multicolumn{2}{c}{ Handwash } & \multicolumn{2}{c}{ Handrub } \\
\cline { 2 - 5 } & $\mathrm{F}$ & $\%$ & $\mathrm{~F}$ & $\%$ \\
\hline Perawat & 13 & 52.0 & 12 & 48.0 \\
Bidan & 3 & 60.0 & 2 & 40.0 \\
Dokter & 2 & 28.6 & 5 & 71.4 \\
\hline
\end{tabular}

\section{PEMBAHASAN}

Berdasarkan hasil observasi, kepatuhan hand hygiene tenaga kesehatan bila dilihat berdasarkan kategori profesi didapatkan hasil bahwa kepatuhan perawat melakukan hand hygiene adalah sebesar 54.3\% dengan 25 tindakan kepatuhan. Angka ini masih jauh dari nilai standar kepatuhan yang ditetapkan oleh rumah sakit yaitu $>80 \%$ padahal poster cara melakukan hand hygiene dengan benar berada di setiap wastafel dan di setiap dinding sebelum masuk ke ruangan pasien. Perawat sebagai tenaga kesehatan yang selama 24 jam berada di sekitar pasien seharusnya dapat mengaplikasikan prosedur hand hygiene yang benar agar dapat meminimalisir terjadinya infeksi silang dari perawat ke pasien demi mencegah terjadinya peningkatan infeksi nosokomial (Puspitasari, 2012).

Pelaksanaan hand hygiene yang tidak dilakukan oleh perawat paling tinggi pada indikasi sebelum kontak dengan pasien dan setelah menyentuh lingkungan pasien. Hal ini disebabkan karena apabila sudah memakai sarung tangan perawat beranggapan tidak perlu melakukan hand hygiene, padahal mengabaikan cuci tangan sebelum menggunakan sarung tangan serta pemakaian sarung tangan yang berulang dari satu pasien ke pasien yang lain dapat menyebabkan transmisi mikroba yang dapat menyebabkan infeksi silang (Potter \& Perry, 2005).

Pada penelitian ini dapat dilihat bahwa tingkat kepatuhan pelaksanaan hand hygiene bidan sebesar 62.5\% dengan 5 tindakan kepatuhan. Kepatuhan tertinggi ada pada momen setelah terpapar cairan tubuh pasien yaitu sebanyak 3 tindakan 
Nur Hidayah, Nur Fadhliyah Ramadhani : Jurnal The Compliance of Health ....

kepatuhan. Hal ini sejalan dengan penelitian Indah Lestari (2014) tentang Kepatuhan Cuci Tangan Petugas Kesehatan di Ruang Rawat Inap Rsup Haji Adam Malik Medan, Bidan merupakan profesi dengan tingkat kepatuhan hand hygiene tertinggi kriteria standar WHO yaitu sebesar 50.60\% (Napitupulu, 2014).

Selama pengamatan yang dilakukan oleh peneliti, bidan sering melakukan hand hygiene karena terpapar langsung oleh darah ataupun cairan tubuh pasien yang lainnya tanpa menggunakan sarung tangan, misalnya membuang infuse set yang sudah terkontaminasi, kantong darah kosong yang jarum infusnya masih melekat darah dan terpegang oleh bidan

Berdasarkan hasil observasi, kepatuhan dokter melakukan hand hygiene adalah sebesar $43.7 \%$ dengan 7 tindakan kepatuhan, Dokter adalah salah satu praktisi kesehatan, namun merupakan profesi dengan tingkat kepatuhan hand hygiene terendah. Bahkan pada momen setelah kontak dengan lingkungan pasien sangat sering dilupakan oleh dokter. Kegiatan dokter yang sering melakukan visite ke pasien sadar maupun tidak sadar tangan mereka sudah menyentuh tempat tidur pasien, tiang infuse, atau selimut pasien (Suryoputri, 2011).

Penelitian ini sejalan dengan pernyataan dari WHO (2009) yaitu hasil observasi menunjukkan minimnya pelaksanaan hand hygiene setelah kontak dengan lingkungan pasien, misalnya peralatan. Hal ini disebabkan karena adanya anggapan bahwa tidak harus mencuci tangan karena tangan tidak terlihat kotor, padahal mikroba dapat berpindah dari pasien ke lingkungan dan benda yang ada di sekitarnya. Saat menyentuh benda yang ada dilingkungan sekitar pasien, tangan dokter mungkin sudah terkontaminasi. Bila sudah terkontaminasi tentu saja hal ini dapat mengakibatkan terjadinya kontaminasi silang ke pasien lain saat dokter melakukan pemeriksaan tanpa mencuci tangan terlebih dahulu lalu memeriksa pasien lain (Potter \& Perry, 2005).

WHO menyatakan bahwa hand hygiene yang efektif melibatkan kesadaran kesehatan, indikasi, dan kapan waktu melakukan hand hygiene. Terdapat "5 momen” dimana tenaga kesehatan harus melakukan hand hygiene diantaraya: Sebelum Kontak dengan Pasien, Sebelum melakukan tindakan aseptic, Setelah 
terpapar cairan tubuh pasien, Setelah kontak dengan pasien, dan Setelah kontak dengan lingkungan pasien (WHO, 2009)

Hasil observasi yang dilakukan memaparkan bahwa masih ada 56.3\% tenaga kesehatan yang tidak melakukan tindakan hand hygiene sebelum kontak dengan pasien, hal ini menunjukkan masih kurangnya kesadaran tenaga kesehatan melakukan hand hygiene sebelum memulai aktivitasnya ataupun saat berpindahan dari satu pasien ke pasien yang lain. Padahal dengan melakukan hand hygiene pasien dapat terlindung dan terhindar dari pathogen yang dibawa oleh tenaga kesehatan (Suryoputri, 2011).

Penelitian yang dilakukan Ernawati 2014 di salah satu rumah sakit di Malang menunjukkan bahwa kepatuhan tenaga kesehatan dalam kegiatan hand hygiene paling jarang dilakukan adalah saat sebelum kontak dengan pasien (48.3\%). Hal ini disebabkan karena beban kerja yang tinggi ditambah jumlah tenaga yang kurang membuat tenaga kesehatan terlalu sibuk dan anggapan bahwa cuci tangan sangat menghabiskan banyak waktu sementara penanganan cepat terhadap pasien adalah hal yang terpenting, maka hampir setengah dari respoden melakukan hand hygiene setelah menangani beberapa pasien dengan alasan untuk mempersingkat waktu (Susilo, 2015).

Tindakan hand hygiene yang dilakukan tenaga kesehatan pada indikasi sebelum tindakan aseptik adalah sebesar $75.0 \%$ dengan 9 tindakan kepatuhan. Pada indikasi sebelum tindakan aseptik sebagian besar tenaga kesehatan tidak melakukan hand hygiene karena telah menggunakan sarung tangan, hal ini apabila dikaitkan dengan alasan mengapa tidak mencuci tangan sejalan dengan pendapat Alvarado 2000 yang dikutip oleh Napitupulu 2014 mengenai "mengapa tenaga kesehatan tidak melakukan hand hygiene” salah satu alasannya adalah anggapan bahwa tindakan hand hygiene tidak perlu ketika sarung tangan dipakai. Bagaimanapun, sarung tangan tidak memberikan perlindungan penuh terhadap kontaminasi bakteri atau patogen pada tangan dan sarung tangan tidak dapat menggantikan perlunya hand hygiene, maka tenaga kesehatan harus mencuci tangan sebelum memakai sarung tangan dan sesudah melepasnya dan sarung tangan juga harus diganti untuk setiap pasien (Fauzia, 2014). 
Nur Hidayah, Nur Fadhliyah Ramadhani : Jurnal The Compliance of Health ....

Pelaksanaan hand hygiene tenaga kesehatan pada indikasi setelah terpapar cairan tubuh pasien adalah sebesar 87.5\%, angka ini menunjukkan bahwa indikasi terpapar cairan tubuh pasien merupakan indikasi dengan tingkat kepatuhan tertinggi. Tenaga kesehatan kebanyakan melakukan hand hygiene hanya ketika tangan mereka bersentuhan langsung dengan cairan tubuh pasien ketika tidak menggunakan sarung tangan. Hasil ini sejalan dengan penelitian yang dilakukan oleh Ernawati 2014 menunjukkan hasil yang sama yaitu berdasarkan observasi terhadap 54 perawat ruang rawat inap didapatkan angka kepatuhan hand hygiene sebesar 35\%, dan kepatuhan tertinggi ditemukan pada indikasi setelah kontak dengan cairan tubuh pasien sebesar 67\% (Ernawati, 2014).

Pelaksanaan hand hygiene tenaga kesehatan pada indikasi setelah kontak dengan pasien adalah sebesar 41.7\%, dan menempati momen dengan tingkat kepatuhan terendah kedua. Pada indikasi ini ketidakpatuhan tenaga kesehatan disebabkan karena saat kontak dengan pasien tenaga kesehatan menggunakan sarung tangan, sehingga tenaga kesehatan merasa tidak perlu lagi melakukan hand hygiene. Menurut WHO 2009 penggunaan sarung tangan baik sarung tangan bersih ataupun steril tidak dapat mengubah atau menggantikan pelaksanaan hand hygiene. Hand hygiene harus dilakukan sebelum mengenakan sarung tangan dan setelah sarung tangan dilepas. Hasil observasi ini sejalan dengan penelitian yang dilakukan oleh Septiani pada tahun 2016 yang menyatakan bahwa kepatuhan hand hygiene pada indikasi setelah kontak dengan pasien hanya sekitar 27\% (Septiani. 2016).

Menurut hasil observasi kepatuhan terendah atau angka tidak cuci tangan paling tinggi adalah pada indikasi setelah menyentuh lingkungan pasien sebesar 85.7\% dengan . Hal ini disebabkan karena tenaga kesehatan menganggap tidak adanya kuman atau patogen berbahaya pada tangan karena tenaga kesehatan tidak menyentuh pasien ataupun terkena cairan tubuh pasien. Padahal kuman juga melekat di lingkungan pasien seperti tempat tidur, laken, tiang infus, linen kotor, dan sebabainya. Hasil ini sejalan dengan penelitian Suryoputri 2011 yang menjelaskan bahwa kepatuhan cuci tangan terendah terjadi pada indikasi setelah menyentuh lingkungan sekitar pasien yaitu 21,27\%. (Suryoputri, 2011). 
Fasilitas yang tersedia di rumah sakit Haji makassar untuk melakukan hand hygiene ada dua cara, yakni menggunakan air dan sabun antimicrobial (handwash) dan alkohol handrub. Untuk handwash telah tersedia wastafel beserta sabun antimikrobial, dan tissue. Sedangkan untuk handrub cairan alcohol handrub telah tersedia di samping pintu masuk setiap ruangan pasien dan di dinding dalam ruangan pasien.

Tindakan cuci tangan menggunakan air dan sabun dilakukan bila tangan terlihat kotor sedangkan penggunaan alcohol handrub untuk hand hygiene dapat dilakukan bila tangan tidak terlihat kotor (WHO, 2009).

Pada penelitian ini didapatkan hasil bahwa penggunaan alcohol handrub lebih tinggi dibanding dengan handwash yaitu sebesar (51,4\%). Penggunaan alcohol handrub maupun handwash berbeda pada setiap kategori profesi. Perawat dan bidan hampir sama dalam penggunaan handwash maupun handrub. Hal ini mengingat bahwa aktivitas bidan dan perawat yang sering kontak langsung dengan pasien, mengakibatkan tangan terlihat kotor sehingga mengharuskan perawat dan bidan melakukan handwash.

Hasil observasi pada penelitian ini menunjukkan bahwa penggunaan handrub lebih dominan digunakan oleh tenaga kesehatan. Hal ini karena produk sejenis alcohol handrub ini dinilai lebih praktis karena tidak memerlukan wastafel dan air mengalir, waktu yang dibutuhkan lebih sedikit dan kecil kemungkinan iritasi pada kulit (Tietjen, dkk, 2004).

Pada penelitian ini tenaga kesehatan masih mengeluhkan masalah sarana untuk hand hygiene, mereka berpendapat bahwa sarana dan prasarana masih kurang memadai. Menurut hasil analisis dan observasi peneliti, sarana dan prasarana yang ada sudah cukup memadai dengan tersedianya wastafel di setiap ruang rawat dan ruang tindakan serta alcohol handrub yang ada di setiap pintu masuk dan di dalam ruangan pasien, serta di trolly yang dibawa petugas bila akan melakukan tindakan. Namun, RSUD Haji masih sangat perlu membenahi sarana dan prasarana untuk melakukan praktek kebersihan tangan dengan penambahan wastafel, penyediaan sabun dan kertas tissue yang memadai, serta alcohol 
Nur Hidayah, Nur Fadhliyah Ramadhani : Jurnal The Compliance of Health ....

handrub yang tersedia di setiap tempat tidur pasien untuk lebih memudahkan tenaga kesehatan dalam melakukan tindakan hand hygiene.

\section{SIMPULAN}

Tingkat pengetahuan tenaga kesehatan mengenai pelaksanaan hand hygiene sudah sangat baik dengan rata-rata tingkat pengetahuan perawat sebesar 78.3\%, bidan sebesar 62.5\% dan dokter sebesar 62.5\%. Tingkat kepatuhan pelaksanaan hand hygiene tenaga kesehatan berdasarkan kategori profesi adalah perawat (54.3\%), bidan (62.5\%), dan dokter (43.7\%). Berdasarkan tiap indikasi hand hygiene kepatuhan tenaga kesehatan pada momen sebelum kontak dengan pasien $43.7 \%$, sebelum tindakan aseptik 75.0\%, setelah terpapar cairan tubuh pasien yang berisiko 87.5\%, setelah kontak dengan pasien $41.7 \%$ dan setelah menyentuh lingkungan sekitar pasien 14.3\%. Berdasarkan penggunaan handwash dan handrub dalam pelaksanaan hand hygiene tenaga kesehatan didapatkan hasil bahwa penggunaan handwash sebesar $49.6 \%$ dan handrub sebesar 51.4\%.

\section{UCAPAN TERIMA KASIH}

Terima kasih kepada Prodi Keperawatan Fakultas Kedokteran dan Ilmu Kesehatan UIN Alauddin Makassar yang telah memberikan dukungan pada pelaksanaan penelitian ini.

\section{DAFTAR PUSTAKA}

Depkes RI. 2008. Pedoman Manajerial Pencegahan dan Pengendalian Infeksi di Rumah Sakit dan Fasilitas Pelayanan Kesehatan Lainnya. Cetakan kedua. Jakarta: Direktorat Jenderal Bina Pelayanan Mediki.

Depkes RI. 2010. Pedoman Pelaksanaan Kewaspadaan Universal di Pelayanan Kesehatan. Cetakan Ketiga. Jakarta: Direktorat Jenderal Pemberantasan Penyakit Menular dan Penyehatan Lingkungan.

Ernawati, E., A. Tri, dan S. Wiyanto. Penerapan Hand Hygiene Perawat di Ruang Rawat Inap Rumah Sakit. Jurnal. Kedokteran Brawijaya. 2014.

Fauzia, Neila. Adherence to the Standard Operating Procedures on Hand Hygiene of Nurses in Hospital's Inpatient Unit. Jurnal. Kedokteran Brawijaya.Vol. 28. Suplemen No. 1. 2014.

Ferdina. 2017. Gambaran Prilaku Hand Hygiene dan Determinannya pada Perawat di ruang Inap Gedung X Rumah Sakit Y Jakarta. Skripsi. Kesehatan Masyarakat. UIN Syarif Hidayatullah.

Hamzah, Zakiyah Ramdlani. Faktor-Faktor Yang Berhubungan Dengan Kinerja perawat Pelaksana Dalam Melaksanakan Pencegahan Infeksi Nosokomial 
Di Ruang Rawat Inap Rumah Sakit Pemerintah Dan Rumah Sakit Swasta Kota Makassar Tahun 2017. Skripsi. Program Studi Kesehatan Masyarakat. UIN Alauddin Makassar. 2017.

Keputusan Menteri Kesehatan RI. Nomor: 129/MenKes/SK/II/2008. Standar Pelayanan Minimal Rumah Sakit.

Keputusan Menteri Kesehatan Nomor 270 /Menkes/SK/III/2007 tentang Pedoman Manajerial Pencegahan dan Pengendalian Infeksi di Rumah Sakit dan Fasilitas Pelayanan Kesehatan Lainnya.

Keputusan Menteri Kesehatan Nomor 382/Menkes/SK/III/2007 tentang Pedoman Pencegahan dan Pengendalian Infeksi di Rumah Sakit dan Fasilitas Kesehatan Lainnya.

Napitupulu. Kepatuhan Cuci Tangan Petugas Kesehatandi Ruang Rawat Inap RSUP Haji Adam Malik Medan. Skripsi. Fakultas Keperawatan Universitas Sumatera Utara. 2014.

Notoadmojo. 2010. Pendidikan dan Prilaku Kesehatan. Jakarta: PT Rineka Cipta. Potter \& Perry. 2005. Fundamental Keperawatan. Volume 1. Jakarta: EGC.

Puspitasari, N. 2012. Gambaran Cuci Tangan Perawat di ruang RA, RB, ICU, CVCU RSUP. H. Adam Malik Medan.

Syamsulastri. Faktor Yang Berhubungan Dengan Kepatuhan Perawat Dalam Melakukan Hand Hygiene Di Rsud Ade Muhammad Djoen Sintang. Skripsi. Program Studi Keperawatan. Universitas Muhammadiyah Pontianak. 2017.

Septiani. Gambaran Faktor-Faktor Yang Mempengaruhi Hand Hygiene Perawat Di Bangsal Ar Royan RS PKU Muhammadiyah Gamping Sleman. Skripsi. Program Studi Ilmu Keperawatan Fakultas Kedokteran Dan Ilmu Kesehatan Universitas Muhammadiyah Yogyakarta. 2016.

Sinaga, S.E.N. 2015. Kepatuhan Hand Hygiene di Rumah Sakit Misi Rangkasbitung. [serial online] [disitasi tanggal 20 Februari 2019]. Diakses dari URL: http://ejournal.stikesborromeus.ac.id/file/6-2.pdf.

Suhartini. Hubungan sikap dengan kepatuhan perawat dalam hand hygiene five momen di ruang kelas III RSUD Sleman. Skripsi. Jogjakarta: Stikes Jenderal Achmad Yani Yogyakarta. 2017.

Suryoputri, A., D. 2011. Perbedaan Angka Kepatuhan Petugas Kesehatan di RSUP DR. Kariadi. Disitasi tanggal 28 Juni 2019 pada: http://eprints.undip.ac.id/32876/1/Atrika_Desi.pdf.

Susilo, Dwi. Bagas. Kepatuhan Pelaksanaan Kegiatan Hand Hygiene Pada Tenaga Kesehatan Di Rumah Sakit X Surabaya. Jurnal Wiyata. 2015.

Tietjen. Bossemeyer, McIntosh, N. 2004. Panduan Pencegahan Infeksi nosokomial untuk Fasilitas Pelayanan dengan Sumber Daya Terbatas. Jakarta: Yayassan Bina Pustaka Sarwono Prawirohardjo bekerja sama dengan JNPKKR/POGI dan JHPIEGO.

Utami, N. Hubungan Kualitas Supervisi Kepala Ruang Terhadap kepatuhan Perawat Melakukan Standar Cuci Tangan di Instalasi Rawat Inap Rst Dr. Soedjono Magelang. Skripsi. PSIK STIKES Ngudi Waluyo Ungaran. 2016.

WHO. 2009. WHO Guidelines on Hand Hygiene in Health Care: First Global Patient Safety Chellenge Clean Care is Safer Care.

WHO. 2016. The Burden Of Health Care-Associated Infection Worldwide. 
